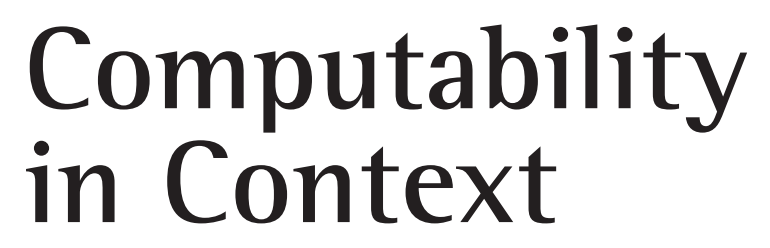

Computation and Logic in the Real World 
This page intentionally left blank 


\title{
Computability in Context
} Computation and Logic in the Real World

\author{
editors \\ S Barry Cooper \\ University of Leeds, UK \\ Andrea Sorbi \\ Università degli Studi di Siena, Italy
}


Published by

Imperial College Press

57 Shelton Street

Covent Garden

London WC2H 9HE

\section{Distributed by}

World Scientific Publishing Co. Pte. Ltd.

5 Toh Tuck Link, Singapore 596224

USA office: 27 Warren Street, Suite 401-402, Hackensack, NJ 07601

UK office: 57 Shelton Street, Covent Garden, London WC2H 9HE

\section{Library of Congress Cataloging-in-Publication Data}

Computability in context : computation and logic in the real world / edited by S. Barry Cooper \& Andrea Sorbi.

p. cm.

Includes bibliographical references.

ISBN-13: 978-1-84816-245-7 (hardcover : alk. paper)

ISBN-10: 1-84816-245-6 (hardcover : alk. paper)

1. Computable functions. 2. Computational intelligence. 3. Set theory.

4. Mathematics--Philosophy. I. Cooper, S. B. (S. Barry) II. Sorbi, Andrea, 1956-

QA9.59.C655 2011

511.3'52--dc22

2010039227

\section{British Library Cataloguing-in-Publication Data}

A catalogue record for this book is available from the British Library.

\section{Copyright (C) 2011 by Imperial College Press}

All rights reserved. This book, or parts thereof, may not be reproduced in any form or by any means, electronic or mechanical, including photocopying, recording or any information storage and retrieval system now known or to be invented, without written permission from the Publisher.

For photocopying of material in this volume, please pay a copying fee through the Copyright Clearance Center, Inc., 222 Rosewood Drive, Danvers, MA 01923, USA. In this case permission to photocopy is not required from the publisher.

Printed in Singapore. 


\section{Preface}

Computability has played a crucial role in mathematics and computer science - leading to the discovery, understanding and classification of decidable/undecidable problems, paving the way to the modern computer era and affecting deeply our view of the world. Recent new paradigms of computation, based on biological and physical models, address in a radically new way questions of efficiency and even challenge assumptions about the so-called Turing barrier.

This book addresses various aspects of the ways computability and theoretical computer science enable scientists and philosophers to deal with mathematical and real world issues, ranging through problems related to logic, mathematics, physical processes, real computation and learning theory. At the same time it focuses on different ways in which computability emerges from the real world, and how this affects our way of thinking about everyday computational issues.

But the title Computability in Context has been carefully chosen. The contributions to be found here are not strictly speaking 'applied computability'. The literature directly addressing everyday computational questions has grown hugely since the days of Turing and the computer pioneers. The Computability in Europe conference series and association is built on the recognition of the complementary role that mathematics and fundamental science plays in progressing practical work; and, at the same time, of the vital importance of a sense of context of basic research. This book positions itself at the interface between applied and fundamental research, prioritising mathematical approaches to computational barriers.

For us, the conference Computability in Europe 2007: Computation and Logic in the Real World was a hugely exciting - and taxing - experience. It brought together a remarkable assembly of speakers, and a level of participation around issues of computability that would surely have astounded Turing and those other early pioneers of 'computing with understanding'. All of the contributions here come from invited plenary speakers or Pro- 
gramme Committee members of CiE 2007. Many of these articles are likely to become key contributions to the literature of computability and its realworld significance. The authors are all world leaders in their fields, all much in demand as speakers and writers. As editors, we very much appreciate their work.

Barry Cooper and Andrea Sorbi 


\section{Contents}

Preface $\quad$ v

1. Computation, Information, and the Arrow of Time 1

P. Adriaans \&3 P. van Emde Boas

2. The Isomorphism Conjecture for NP

M. Agrawal

3. The Ershov Hierarchy

M. M. Arslanov

4. Complexity and Approximation in Reoptimization

G. Ausiello, V. Bonifaci, \& B. Escoffier

5. Definability in the Real Universe

S. B. Cooper

6. HF-Computability

Y. L. Ershov, V. G. Puzarenko, \& A. I. Stukachev

7. The Mathematics of Computing between Logic and Physics

G. Longo \& T. Paul 
8. Liquid State Machines: Motivation, Theory, and Applications 275 W. Maass

9. Experiments on an Internal Approach to Typed Algorithms in Analysis

D. Normann

10. Recursive Functions: An Archeological Look P. Odifreddi

11. Reverse Mathematics and Well-ordering Principles M. Rathjen \&3 A. Weiermann

12. Discrete Transfinite Computation Models P. D. Welch 